\title{
PENGARUH KUALITAS PRODUK, KUALITAS PROSES, KUALITAS PELAYANAN DENGAN PERAN MEDIASI KEPUASAN PELANGGAN TERHADAP LOYALITAS PELANGGAN
}

\author{
I Dewa Nyoman Usadha
}

Fakultas Ekonomi, Universitas Mahendradatta, Jl. Ken Arok No.12, Peguyangan, Denpasar Utara, Kota Denpasar, Bali 80115

Telp/Fax :(0361) 434827/0361-249471,

\begin{abstract}
This study is an empirical study in coastal areas or coastal villages in the region of Tabanan. which aims to determine the effect of Product Quality, process quality, service quality with mediation satisfaction to Loyalty of small and medium business customers. Methodelogi used, Statistics method with Moderation or Mediation variables. The number of samples taken from the population of 30 respondents. The results showed the relationship of Product Quality (X1) to the quality of process (X2) 0.971, Quality of service (X3) 0.795 so that the average relationship 0.883 , with the mediation 0.816 so as to produce the level of customer satisfaction 0.818 . The correlation of process quality $(X 2)$ with product quality $(X 1)$ 0,971, Service Level (X3) 0,846, average 0,908 mediated correlation 0,850 resulted Customer Loyalty level 0,842, with mediation equal to 0,850 resulted Average Customer Loyalty 0,58 process quality, product quality and service level. Relationship Level of Service Quality (X3) 0,846 with process quality (X1) 0,795, with average 0,820 with mediation 0,971 resulted high customer satisfaction 0,826. So with a mediation of 0.971 mediate the median level of 0.771 . Which the average relationship of 0.820 with mediation 0.971 resulted in the level to the average customer Loyalty of -0.151.the relationship that has been established either does not require the level of mediation
\end{abstract}

Keywords, Product quality, process, service, Satisfaction, Loyaitas customer 


\section{Pendahuluan.}

Wirausaha menjadi pilihan masyarakat desa pesisir karena seiring dengan kemajuan wisata secara sporadis terjadi perubahan alih fungsi alam, alih kemilikan hingga alih profesi, awalnya sebagai petani karena menyempitnya lahan dan tata kelola pertanian saat ini tidak signifikan dengan biaya yang dikeluarkann ,begitu pula tani garam juga berangsur ditinggalkan karena hasil produknya tidak mampu bersaing . Nelayan tradisional dari kalangan muda juga belum tertarik menekuninnya ,mereka masih mengidamkan penawaran peluang kerja dari lembaga atau institusi formal yang terbatas adanya. Tidak pilihan bagi sumber daya manusia Desa pesisir kecuali mengembangkan usaha Wirausaha. Beberapa decade terahkir ini banyak masyarakat desa sudah menukuni barbagai kegiatan bisnis namun demikian dalam situasi persaingan bagaimana usaha mereka menjaga hubungan dengan kostumer sehingga para pelanggan sedapat mungkin mengapresiasi terhadap produk yang ditawarkan dari segi kualitas, dari segi proses terhadap efesiensi ,termasuk juga pola pelayanan, hal ini akan menciptakan loyalis para kostumer.

Penelitian ini tentangpengaruh Kualitas Produk ,kualitas proses ,kualitas pelayananan dengan mediasi kepuasan terhadap Loyalitas Usaha Kecil Menengah (UKM) di wilayah pesisir atau Desa Pantai di Wilayah Tabanan .

Tabanan memiliki Wilayah Desa pantai panjang dan sangat subur ,airnya dengan sangat mudah didapat apalagi diperkuat dengan sistem subak. Posisi gunung,atau tanah berbukit sabagai peresapan air jaraknya rata-rata $35 \mathrm{~km}$ profesi bercocok tanam padi menjadi pilihan utama di wilayah ini oleh karenannya Tabanan sering dijuluki lumbung berasnya Bali .kami lahan-pesisir pantai dulu adalah lahan pertanian luas, profesi penduduknya adalah bercocok tanam, nelayan, tani garam Pada tahun 1980 secara seporadis terjadi perubahan fundamental diwilayah pesisir Tabanan karena dampak pariwisata yang meluas dikawasan Bali yang menyisir wilayah pantai. Alih kepemilikan lahan pertanian dikawasan pantai Tabanan berhangsur angsur trejadi yang lebih draktis terjadi pada tahun 1998 ,setelah pemerintah reformasi mengeluarakan kuputusa Otonomi Daerah . Banyak para pejabat berpacu dalam meningkatan Pendapatan Asli daerah (PAD) dengan mengundang investor ,atau menerima investor untuk membangun investasi bidang pariwsata dan akomodasi perhotelan, tanpa jeli melihat dampak turunnya yakni alih pungsi lahan, diikuti dengan kelangkaan kesempatan bekerja, alih profesi dari petani bercocok tanam menjadi tungkang musiman dibidang bangunan, pengagguran pemuda (tenaga potensial ) yang tidak memiliki ketrampilan, tani nelayan dan tani garam ditinggalkan. Pendatang ke wiayah desa pesisir pun mengabil porsi peluang kerja disbanding masyarakat local.

Para tokoh masyarakat Desa pantai mulai menyadari, menjual tanah jorjoran kepada investor karena berpendapat wilayah desa akan maju pula tidak sepenuhnya benar ,karena terjadi perubahan mendasar, alih 
kepemilikan, alih fungsi lahan, alih Profesi tetapi masyarakat belum sepenuhnya menyadari sehinga lambat laun terjadi persaingan besar setelah wilayahnya terbuka untuk pariwisata. Tidak ingin kehilangan identitas ( seperti masyakat Betawi tergerus-tergusur ) maka beberapa masyakat Desa pantai memilih profesi wirausaha sebagai pilihan, baik secara berkelompok maupun mandiri secara pribadi. Yang menjadi pertimbangan dan professional dalam mengelola usaha adalah kepuasan dan loyalitas pelanggan/konsumen.

Variabel yang berpengaruh terhadap kepuasan tergantung pada variabel kualitas produk, variabel kualitas proses. Variabel kualitas produk dan variabel kualitas proses sudah terbentuk disertai dengan variabel kualitas pelayanan sehingga berpengaruh terhadap kepuasan pelanggan dapat tercapai dan berpegaruh terbentuknya opini pelanggan merasa puas, sehingga berdampak hubungan fisikologis yakni loyalitas. Sehingga dalam penelitian ini dapat kami formulasikan kedalam judul ;"PENGARUH KUALITAS PRODUK, KUALITAS PROSES, KUALITAS PELAYANAN DENGAN PERAN MEDIASI KEPUASAN PELANGGAN TERHADAP LOYALITAS PELANGGAN

\section{Kajian Teori}

Grand teory penelitian ini mengambil teory Kotler, Philip dan Gary Armstrong. 2003. Dasar-dasar Pemasaran Jilid ldimana Kualitas

Produkmenurut Kotler dan Armstrong (2003:347) mengatakan bahwa kualitas produk mempunyai dua dimensi yang sangat berpengaruh, yaitu tingkatan yaitu mengembangkan sebuah produk pemasar harus pintar memilih tingkatan kualitas yang dapat membantu sebuah produk agar mudah masuk ke dalam pasar yang ditargetkan. Dimensi konsistensi adalah kualitas dan standar yang tinggidilakukansebagai

konsistensi dalam memberikan produk dengan kualitas yang terbaik.

Boyd, Walker dan Larreche (2006:272)selanjutnya mengidentifikasi delapan dimensi pengukurankualitas produkyang terdiri atas aspek -aspek, yaitu kinerja (performance), ciri khasproduk (features),keandalan (reability),kesesuaian

(conformance),ketahanan atau daya tahan (durability),kemampuan pelayanan (serviceability)estetika (aesthetics), dan kualitas yang dipersepsikan (perceived quality)Kualitas menjadi fokus utama bisnis di dunia.

Berbagai perusahaan menggunakan standar dan pedoman manajemen kualitas. Dalam perdagangan global standar untuk mengukur kualitas diperlukan, seperti kualitas standar internasional. "Selain standar yang berlaku dan ditetapkan di negara-negara tertentu, terdapat juga standar yang berlaku secara internasional. Salah satu diantaranya adalah ISO 9000 yang sertifikasinya ditetapkan oleh International Organization for Standardization(ISO) di Jenewa, Swiss. 
Kualitas PelayananJasa dalm konteks bisnis internasional disebut dengan jasa internasional. Menurut Clark, Rajatnam dan Smith(1996)dalam Tjiptono dan Chandra (2005:20) jasa internasional bisa diklasifikasikan menjadi empat macam: contactbased services, vehicle-based services, aset-based service, dan object-based services.Menurut Lewis dan Booms (1983) dalam Tjiptono dan Chandra (2005:121), kualitas jasa adalah ukuran seberapa bagus tingkat layanan yang diberikan mampu sesuai dengan ekspektasi pelanggan. Menurut Simamora (2003:180) ada dua faktor utama yang mempengaruhi kualitas layanan.Pertama, expected serviceadalah apabila layanan yang diterima sesuai dengan yang diharapkan maka kualitas layanan dipersepsikan memuaskan Kedua, perceived serviceadalahlayanan yang diterima melampaui pelanggan maka bisa dipersepsikan sebagai kualitas yang ideal.

Parasuraman, Zeithaml, dan Berry (1985) dalam Tjiptono, Chandra, Adriana (2008:73) memperkenalkan model Servqual .Model servqualadalah model pengukuran kualitas jasa. Model ini lebih menekankan multi-item yang dirancang untuk mengukur expected servicesdan perceived services, dimana dimensi kualitas dibagimenjadi lima variabel yaitukeandalan (reability), daya tanggap (responsiveness), Jaminan (warranty), empati (emphaty), dan bukti fisik (tangible). Pelanggan Lintas
BudayaPerusahaan global ketika melakukan ekspansi ke negara lain perlu melakukan analisis tentang kriteria konsumen di negara yang akan dituju. "Perbedaan kebudayaan yang mempengaruhi adalah bahasa dan nilai. Bahasa dapat menghambat proses komunikasi dan nilai mempunyai pengaruh yang lebih tajam" (Mowen dan Minor,2002:351). Pemasar harus mempelajari perbedaan selera setiap konsumen di negara sasaran. Pemasar perlu melakukan adaptasi produk agar produk tersebut diterima di negara sasaran. Budaya konsumen di setiap negara dapat dipandang sebagai sebuah contoh atau sejenis budaya materi, artinya adalah konsumsi merupakan proses budaya seperti proses ekonomi. Analisis komparatif diperlukan untuk menguji perbedaan antar budaya.Metode menguji perbedaan antar budayadigunakan untuk membedakan aspek-aspek universal dari kebudayaan manusia dan organisasi sosial dari sebagian kelompok sosial atau individu dari masyarakat tertentu(Lury, 1998:74). Kebangkitan budaya konsumen dicirikan dengan peningkatan gaya hidup dan pemanfaatan barang-barang konsumen lebih terstruktur.

Kepuasan dan Loyalitas PelangganKepuasan konsumen adalah konsep penting pada pemasaran dan penelitian konsumen. Konsumen merasa puas dengan suatu produk atau 
merek akan cenderung membeli dan memakainya Serta memberitahu orang lain tentang pengalaman yang menyenangkan dengan produk tersebut (Peter dan Olson, 1999:157).Giese dan Cote (2000) dalam Tjiptono dan Chandra (2005:196) berpendapat bahwa definisi kepuasan tidak bisa lepas dari chameleon effects.Chameleon effectsartinya intrepertasi terhadap definisi sangat bervariasi antar individu dan antar situasi.

Pendekatan lainnya untuk memahami kepuasan konsumen adalah dengan menggunakan teori keadilan. Teori ini berpendapat bahwa masyarakat akan menganalisis rasio hasil (outcomes)dan masukan (input). Bila terlihat salah satu rasionya lebih tinggi maka bisa dikatakan bahwa pelanggan mengalami perasaan tidak adil (Mowen dan Minor, 2001:96).Fornell (1992) dalam Tjiptono (2006:362) menjelaskan bahwa,"indeks kepuasan pelanggan nasional bisa menjadi komplemen penting bagi ukuran tradisional kinerja ekonomi. Karenakepuasan pelanggan nasionalbisa memberikan informasi bermanfaat Informasi tersebut akan disalurkan keperusahaan, pemegang saham, investor, pemerintah, dan konsumenKepuasan pada pelanggan berdampak pada loyalitas pelanggan, menurut Griffin (2003:5) konsep loyalitas pelanggan lebih banyak dikaitkan dengan perilaku daripada sikap. Perilaku adalah ketika pelanggan melakukan pembelian. Sedangkan, sikapadalah perasaan yang ditunjukkan oleh pelanggan setelah menggunakan produk.Pelangganyangloyal,

Akanmenunjukkan perilaku pembelian yang Dilakukandari waktu ke waktuPelanggan yang loyal mempunyai peran yang sangat penting bagi perusahaan, karena loyalitas seorang pelanggan bisa meningkatkan laba dan mempertahankan eksistensi sebuah perusahaan (Hurriyati, 2008:128).Griffin (2003:31) mengidentifikasi tentang pelanggan yang loyal dengan cirri -ciri seperti, melakukan pembelian ulang secara teraturmembeli antarlini produk dan jasamereferensikan kepada orang laindan menunjukkan kekebalan terhadap tarikan dari pesaing-pesaing

3. Metodelogi

Metodelogi yang dipergunakan ,metode Statistika dengan variabel Moderasi dan Mediasi. Variabel yang bersifat memperkuat atau memperlemah pengaruh variabel predictor atau penjelas (independent) terhdapa variabel respon atau tergantung (dependent). Salah satu cirri yang penting variabel ini adalah bahwa variabel moderasi tidak dipengaruhi oleh variabel penjelas.

\subsection{Popolasi dan sample}

Popolasi Desa Wilayah Pesisir Tabanan, dengan mengambil contoh sample sebanyak 30 pelaku Usaha Kecil menengah (UKM)

Kerangka konsep : 


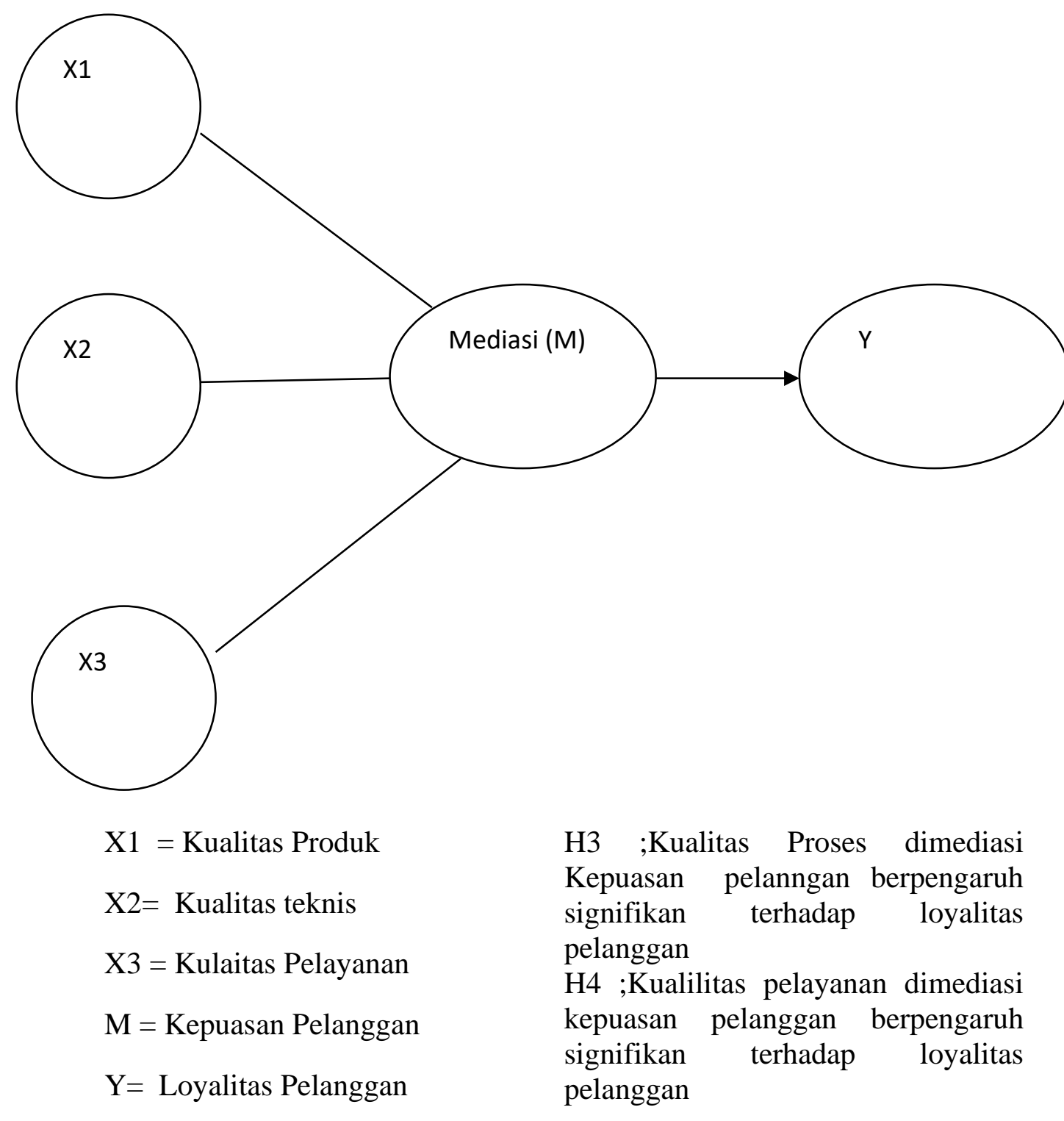

\subsection{Hipotesis :}

H1 ;Kualitas Produk .Kualitas Proses ,Kualitas pelayanan berpengaruh signifikan terhadap Kepuasan Pelanggan

H2 :Kualitas Produk dimederasi Kepuasan pelanngan memiliki pengaruh signifikan terhdapa loyalitas pelanggan.

\section{Pembahasan}

Aplikasi Model Variabel Mediasi, Kualitas Produk(X1) Kualitas proses (X2), Kualitas Pelayanan (X3) , Kepuasan Pelanggan (Mediasi) terhadap Loyalitas Pelanggan 


\begin{tabular}{|c|c|c|c|}
\hline & Mean & Std. Deviation & $\mathrm{N}$ \\
\hline KUALITAS PRODUK & 35.47 & 5.022 & 30 \\
\hline KUALITAS PROSES & 35.27 & 5.601 & 30 \\
\hline KUALITAS PELAYANAN & 33.93 & 6.913 & 30 \\
\hline KEPUASAN .PELANGGAN & 34.30 & 5.902 & 30 \\
\hline MEDIASI & 35.03 & 6.100 & 30 \\
\hline PERAN MEDIASI & 35.43 & 5.049 & 30 \\
\hline
\end{tabular}

\begin{tabular}{|c|c|c|c|c|c|c|c|}
\hline \multicolumn{8}{|c|}{ Correlations } \\
\hline & & $\begin{array}{c}\text { KUA } \\
\text { PRODU } \\
\text { K }\end{array}$ & $\begin{array}{c}\text { KUA } \\
. \text { PROSES }\end{array}$ & $\begin{array}{l}\text { KUA } \\
\text { PELAYANAN }\end{array}$ & $\begin{array}{c}\text { KEP,PELA } \\
\text { NGGAN }\end{array}$ & MEDIAS & $\begin{array}{l}\text { PERAN } \\
\text { MEDIASI }\end{array}$ \\
\hline \multirow{6}{*}{$\begin{array}{l}\text { Pearson } \\
\text { Correlatio } \\
n\end{array}$} & KUALITAS PRODUK & 1.000 & .971 & .795 & .818 & .816 & .832 \\
\hline & KUALITAS PROSES & .971 & 1.000 & .846 & .850 & .850 & .842 \\
\hline & KUA.PELAYANAN & .795 & .846 & 1.000 & .826 & .971 & .771 \\
\hline & KEP,PELANGGAN & .818 & .850 & .826 & 1.000 & .760 & .959 \\
\hline & MEDIASI & .816 & .850 & .971 & .760 & 1.000 & .740 \\
\hline & PERAN MEDIASI & .832 & .842 & .771 & .959 & .740 & 1.000 \\
\hline \multirow{6}{*}{$\begin{array}{l}\text { Sig. (1- } \\
\text { tailed) }\end{array}$} & KUA. PRODUK & & .000 & .000 & .000 & .000 & .000 \\
\hline & KUA. PROSES & .000 & & .000 & .000 & .000 & .000 \\
\hline & KUA. PELAYANAN & .000 & .000 & & .000 & .000 & .000 \\
\hline & KEP,PELANGGAN & .000 & .000 & .000 & & .000 & .000 \\
\hline & MEDIASI & .000 & .000 & .000 & .000 & & .000 \\
\hline & PERAN MEDIASI & .000 & .000 & .000 & .000 & .000 & \\
\hline \multirow[t]{6}{*}{$\mathrm{N}$} & KUA. PRODUK & 30 & 30 & 30 & 30 & 30 & 30 \\
\hline & KUA. PROSES & 30 & 30 & 30 & 30 & 30 & 30 \\
\hline & KUA. PELAYANAN & 30 & 30 & 30 & 30 & 30 & 30 \\
\hline & KEP,PELANGGAN & 30 & 30 & 30 & 30 & 30 & 30 \\
\hline & MEDIASI & 30 & 30 & 30 & 30 & 30 & 30 \\
\hline & PERAN MEDIASI & 30 & 30 & 30 & 30 & 30 & 30 \\
\hline
\end{tabular}

DekripsiCorelationVariabel

1. Hubungan Kualitas Produk (X1)dengan (X2) kualitas proses 0,971 , Kualitas pelayanan(X3 ) 0,795 sehingga hubungan rataratanya 0,883 , dengan di mediasi 0,816 sehingga menghasilakan tingkat kepuasan pelangga sebesar 0,818 artinya dengan tingkat kepuasan pelanggan 0,818 serta dimediasi sebesar 0,816 menghasilkan tingkat Loyalitas pelanggan sebesar 0,832 mengalani peningkatan tingkat Loyalitas pelanggan sebesar 0,67 terhadapkualitasproduk, kualitas proses sertatingkatpelayanan.

2. Hubungan kualitas proses (X2) dengan kualitas produk (X1) 0,971, Tingkat Pelayanan(X3) 0,846 , rata-rata hubungan 0,908 dimediasi sebesar 0,850 menghasilkan tingkat Loyalitas pelanggan 0,842 , dengan mediasi sebesar 0,850 menghasilkan tingkat Loyalitas pelanggan ratarata 0,58 terhadap kualitas proses, 
kualitas produk dan tingkat pelayanan

3. Hubungan Tingkat Kualitas pelayanan (X3) 0,846 dengan kualitas proses (X1) 0,795, dengan rata-rata 0,820 dengan mediasi 0,971 mengahasilkan tinggkat kepuasan pelanggan 0,826. Jadi dengan mediasi 0,971mengahasilakan tinggkat mediasi sebesar 0,771. Yang mana rata-rata hubungan sebesar 0,820 dengan mediasi 0,971 menghasilakan tingkat ke Loyalitas pelanggan rata-rata sebesar -0,151.artinya hubungan yang telah terjalin baik tidak memerlukan tingkat mediasi.

\begin{tabular}{|c|c|c|c|c|c|c|c|c|c|c|}
\hline \multirow[b]{2}{*}{ Model } & \multirow[b]{2}{*}{$\mathrm{R}$} & \multirow[b]{2}{*}{$\begin{array}{c}\text { R } \\
\text { Square }\end{array}$} & \multirow[b]{2}{*}{$\begin{array}{c}\text { Adjusted } \\
\text { R } \\
\text { Square }\end{array}$} & \multirow{2}{*}{\begin{tabular}{|c} 
Std. \\
Error of \\
the \\
Estimate
\end{tabular}} & \multicolumn{5}{|c|}{ Change Statistics } & \multirow[b]{2}{*}{$\begin{array}{l}\text { Durbin- } \\
\text { Watson }\end{array}$} \\
\hline & & & & & $\begin{array}{c}\text { R } \\
\text { Square } \\
\text { Change }\end{array}$ & $\begin{array}{c}\text { F } \\
\text { Change }\end{array}$ & df1 & df2 & $\begin{array}{c}\text { Sig. F } \\
\text { Change }\end{array}$ & \\
\hline 1 & $.976^{a}$ & .952 & .942 & 1.205 & .952 & 95.875 & 5 & 24 & .000 & 2.093 \\
\hline
\end{tabular}

Berdasarkan R Square sebesar 0,952 atau 95,2 \% yang berarti bahwa prosentase variabel independen terhadap variabel devendent Loyalitas Pelanggan yang tidak mendekati angka 1 berpengaruh negative. Koefisien Determinasi yaitu $95,2 \%$ sedangkan sisanya $0,8 \%$ merupakan pengaruh variabel lain yang tidak dimasukan dalam model ini.

Nilai R merupakan koefesien korelasi dengan nilai 0,976 atau $97,6 \%$ menunjukan bahwa korelasi atau hubungan antara variabel indevenden dan devenden ,Loyalitas Pelanggan sangat tinggi

ANOVA $^{a}$

\begin{tabular}{|l|l|r|r|r|r|r|}
\hline \multicolumn{2}{|l|}{ Model } & Sum of Squares & Df & Mean Square & F & Sig. \\
\hline \multirow{3}{*}{1} & Regression & 696.592 & 5 & 139.318 & 95.875 & $.000^{\mathrm{b}}$ \\
\cline { 2 - 7 } & Residual & 34.875 & 24 & 1.453 & & \\
\cline { 2 - 7 } & Total & 731.467 & 29 & & & \\
\hline \multicolumn{2}{l}{ a. Dependent Variable: LOYALITAS PELANGGAN } \\
\hline
\end{tabular}

b. Predictors: (Constant), PERAN MEDIASI, MEDIASI, KUALITAS PRODUK, KUALITAS KERJA KEP,PELANGGAN, PELAYANAN

Pengujian secara silmutan bahwa nilai $\mathrm{F}_{-}$hitung untuk model regresi adalah 95.875 dengan tingkat significan $0,000<0,05$ maka tingkat significan model regresi lebih kecil dari taraf nyata - Hasil ini menunjukan bahwa variabel bebas secara bersama sama berpengaruh terhadap variabel devinden.

\begin{tabular}{|c|c|c|c|c|c|c|c|c|c|c|c|}
\hline \multicolumn{12}{|c|}{ Coefficients $^{a}$} \\
\hline \multirow{2}{*}{\multicolumn{2}{|c|}{ Model }} & \multicolumn{2}{|c|}{$\begin{array}{c}\text { Unstandardized } \\
\text { Coefficients }\end{array}$} & \multirow{2}{*}{$\begin{array}{c}\text { Standardized } \\
\text { Coefficients } \\
\text { Beta } \\
\end{array}$} & \multirow[b]{2}{*}{$\mathrm{T}$} & \multirow[b]{2}{*}{ Sig. } & \multicolumn{3}{|c|}{ Correlations } & \multicolumn{2}{|c|}{$\begin{array}{l}\text { Collinearity } \\
\text { Statistics }\end{array}$} \\
\hline & & $\mathrm{B}$ & $\begin{array}{l}\text { Std. } \\
\text { Error }\end{array}$ & & & & $\begin{array}{l}\text { Zero- } \\
\text { order }\end{array}$ & Partial & Part & Tolerance & VIF \\
\hline \multirow[t]{6}{*}{1} & (Constant) & 2.362 & 1.886 & & 1.252 & .223 & & & & & \\
\hline & $\begin{array}{l}\text { KUALITAS } \\
\text { PRODUK }\end{array}$ & .859 & .098 & .958 & 8.789 & .000 & .971 & .873 & .392 & .167 & 5.976 \\
\hline & PELAYANAN & -.244 & .196 & -.336 & -1.244 & .225 & .795 & -.246 & $.055^{-}$ & .027 & 36.796 \\
\hline & KEP,PELANGGAN & -.058 & .193 & -.069 & -.302 & .766 & .818 & -.061 & .013 & .038 & 25.986 \\
\hline & MEDIASI & .220 & .204 & .267 & 1.080 & .291 & .816 & .215 & .048 & .032 & 30.773 \\
\hline & PERAN MEDIASI & .153 & .186 & .154 & .823 & .419 & .832 & .166 & .037 & .057 & 17.517 \\
\hline
\end{tabular}

I Dewa Nyoman Usadha 
Berdasasarkan hasil persamaan regresi linear diatas diatas maka dapat dijelaskan sebagai berikut :

1. Koefisen Regresi Kualitas Produk $(\mathrm{X} 2)=0,958$ berarti

Berdasasarkan hasil persamaan regresi linear diatas diatas maka dapat dijelaskan sebagai berikut :

1. Koefisen Regresi Kualitas Produk $(\mathrm{X} 2)=0,958$ berarti Kualitas kerja berpengaruh
Kualitas kerja berpengaruh signifikan terhadap Loyalitas pelanggan

Koefisien Regresi Pelayanan (X3) = - 0,336 berarti tidak signifikan

signifikan terhadap Loyalitas pelanggan

2. Koefisien Regresi Pelayanan $(\mathrm{X} 3)=-0,336$ berarti tidak signifikan

\section{Coefficient Correlations ${ }^{a}$}

\begin{tabular}{|c|c|c|c|c|c|c|c|}
\hline \multicolumn{3}{|c|}{ Model } & $\begin{array}{l}\text { PERAN } \\
\text { MEDIASI }\end{array}$ & MEDIASI & $\begin{array}{l}\text { KUALITAS } \\
\text { PRODUK }\end{array}$ & $\begin{array}{l}\text { KEP,PELAN } \\
\text { GGAN }\end{array}$ & PELAYANAN \\
\hline \multirow[t]{10}{*}{1} & \multirow[t]{5}{*}{$\begin{array}{l}\text { Correlation } \\
\mathrm{s}\end{array}$} & $\begin{array}{l}\text { PERAN } \\
\text { MEDIASI }\end{array}$ & 1.000 & -.457 & -.057 & -.885 & .507 \\
\hline & & MEDIASI & -.457 & 1.000 & -.384 & .611 & -.938 \\
\hline & & $\begin{array}{l}\text { KUALITAS } \\
\text { PRODUK }\end{array}$ & -.057 & -.384 & 1.000 & -.236 & .194 \\
\hline & & $\begin{array}{l}\text { KEP,PELANGG } \\
\text { AN }\end{array}$ & -.885 & .611 & -.236 & 1.000 & -.685 \\
\hline & & PELAYANAN & .507 & -.938 & .194 & -.685 & 1.000 \\
\hline & \multirow[t]{5}{*}{$\begin{array}{l}\text { Covarianc } \\
\text { es }\end{array}$} & $\begin{array}{l}\text { PERAN } \\
\text { MEDIASI }\end{array}$ & .034 & -.017 & -.001 & -.032 & .018 \\
\hline & & MEDIASI & -.017 & .041 & -.008 & .024 & -.038 \\
\hline & & $\begin{array}{l}\text { KUALITAS } \\
\text { PRODUK }\end{array}$ & -.001 & -.008 & .010 & -.004 & .004 \\
\hline & & $\begin{array}{l}\text { KEP,PELANGG } \\
\text { AN }\end{array}$ & -.032 & .024 & -.004 & .037 & -.026 \\
\hline & & PELAYANAN & .018 & -.038 & .004 & -.026 & .039 \\
\hline
\end{tabular}




\section{CollinearityDiagnostics ${ }^{a}$}

\begin{tabular}{|c|c|c|c|c|c|c|c|c|c|}
\hline \multirow[b]{2}{*}{ Model } & \multirow[b]{2}{*}{$\begin{array}{l}\text { Dime } \\
\text { nsion }\end{array}$} & \multirow[b]{2}{*}{ Eigenvalue } & \multirow[b]{2}{*}{$\begin{array}{l}\text { Condition } \\
\text { Index }\end{array}$} & \multicolumn{6}{|c|}{ Variance Proportions } \\
\hline & & & & $\begin{array}{c}\text { (Const } \\
\text { ant) }\end{array}$ & $\begin{array}{l}\text { KUALITAS } \\
\text { PRODUK }\end{array}$ & $\begin{array}{c}\text { PELAYANA } \\
\mathrm{N}\end{array}$ & $\begin{array}{l}\text { KEP,PELAN } \\
\text { GGAN }\end{array}$ & $\underset{\mid}{\text { MEDIAS }}$ & $\begin{array}{l}\text { PERAN } \\
\text { MEDIAS } \\
\text { । }\end{array}$ \\
\hline \multirow[t]{6}{*}{1} & 1 & 5.961 & 1.000 & .00 & .00 & .00 & .00 & .00 & .00 \\
\hline & 2 & .023 & 16.086 & .39 & .00 & .01 & .00 & .00 & .00 \\
\hline & 3 & .010 & 23.854 & .15 & .00 & .01 & .03 & .02 & .02 \\
\hline & 4 & .004 & 39.669 & .06 & .82 & .03 & .02 & .00 & .01 \\
\hline & 5 & .001 & 70.130 & .39 & .11 & .11 & .14 & .19 & .36 \\
\hline & 6 & .000 & 133.171 & .01 & .06 & .84 & .80 & .79 & .61 \\
\hline
\end{tabular}

\section{Residuals Statistics ${ }^{a}$}

\begin{tabular}{|l|r|r|r|r|r|}
\hline & \multicolumn{1}{|c|}{ Minimum } & Maximum & \multicolumn{1}{c|}{ Mean } & Std. Deviation & $\mathrm{N}$ \\
\hline Predicted Value & 29.96 & 48.79 & 35.47 & 4.901 & 30 \\
\hline Residual & -2.016 & 2.539 & .000 & 1.097 & 30 \\
\hline Std. Predicted Value & -1.124 & 2.719 & .000 & 1.000 & 30 \\
\hline Std. Residual & -1.673 & 2.106 & .000 & .910 & 30 \\
\hline
\end{tabular}

a. Dependent Variable: Loyalitas

\begin{tabular}{|c|c|c|c|c|c|c|c|c|c|}
\hline \multicolumn{10}{|c|}{ CollinearityDiagnostics $^{a}$} \\
\hline \multirow[b]{2}{*}{$\begin{array}{l}\text { Mod } \\
\text { el }\end{array}$} & \multirow[b]{2}{*}{$\begin{array}{l}\text { Dimensi } \\
\text { on }\end{array}$} & \multirow[b]{2}{*}{$\begin{array}{c}\text { Eigenval } \\
\text { ue }\end{array}$} & \multirow[b]{2}{*}{$\begin{array}{l}\text { Conditi } \\
\text { on } \\
\text { Index }\end{array}$} & \multicolumn{6}{|c|}{ Variance Proportions } \\
\hline & & & & $\begin{array}{c}\text { (Consta } \\
\text { nt) }\end{array}$ & $\begin{array}{c}\text { KUA } \\
\text { KERJ } \\
\text { A }\end{array}$ & $\begin{array}{l}\text { KUA. } \\
\text { PROSE } \\
\text { S }\end{array}$ & $\begin{array}{c}\text { KEP } \\
\text {,PELANGG } \\
\text { AN }\end{array}$ & $\begin{array}{c}\text { MEDIA } \\
\text { SI }\end{array}$ & $\begin{array}{l}\text { PERAN } \\
\text { MEDIA } \\
\text { SI }\end{array}$ \\
\hline \multirow[t]{6}{*}{1} & 1 & 5.961 & 1.000 & .00 & .00 & .00 & .00 & .00 & .00 \\
\hline & 2 & .023 & 16.086 & .39 & .00 & .01 & .00 & .00 & .00 \\
\hline & 3 & .010 & 23.854 & .15 & .00 & .01 & .03 & .02 & .02 \\
\hline & 4 & .004 & 39.669 & .06 & .82 & .03 & .02 & .00 & .01 \\
\hline & 5 & .001 & 70.130 & .39 & .11 & .11 & .14 & .19 & .36 \\
\hline & 6 & .000 & $\begin{array}{r}133.17 \\
1\end{array}$ & .01 & .06 & .84 & .80 & .79 & .61 \\
\hline
\end{tabular}

I Dewa Nyoman Usadha 


\begin{tabular}{|l|r|r|r|r|r|}
\hline \multicolumn{7}{|c|}{ Residuals Statistics $^{\mathbf{a}}$} \\
\hline & Minimum & Maximum & \multicolumn{1}{c|}{ Mean } & Std. Deviation & $\mathrm{N}$ \\
\hline Predicted Value & 29.96 & 48.79 & 35.47 & 4.901 & 30 \\
\hline Residual & -2.016 & 2.539 & .000 & 1.097 & 30 \\
\hline Std. Predicted Value & -1.124 & 2.719 & .000 & 1.000 & 30 \\
\hline Std. Residual & -1.673 & 2.106 & .000 & .910 & 30 \\
\hline a. Dependent Variable: LOYALITAS PELANGGAN & \multicolumn{3}{|c|}{} \\
\hline
\end{tabular}

4.2 Analisis: KoefisienDeterminasi Nilai Adjusted R Square (R2) sebesar 0,942 , artinya $94 \%$ variasi $\mathrm{Y}$ dapat dijelaskan oleh variabel independen kualitas produk (X1) 0,859, kualitas proses ( X2) $-0,244$ dan Kua pelayanan (X3) -0,058, yang mana tingkat kualitas proses dan pelayanan sangat rendah terhadap Loyalitas pelanggan. Sisanya $(100 \%-94,0 \%=$ $06,0 \%$ ) dijelaskan oleh sebab-sebab lain di luar model.

4.3 Uji Signifikansi Simultan

(UjiStatistik F)

Uji Anovaatau $F$ test menghasilkan nilai $\mathrm{F}$ hitung sebesar 95,87dengan tingkat signifikansi 0,000. Karena probabilitas signifikansi jauh lebih kecil dari 0,05, maka model regresi dapat digunakan untuk memprediksi Loyalitas Pelanggan (Y) atau dapat dikatakan bahwa kualitas Produk (X1), Kua Pelayanan (X3), dan secara bersamasama berpengaruh terhadap Loyalitas Pelanggan (Y).

4.4 Uji Signifikansi coefficetionts Individual

\subsection{1 (Uji t Statistik)}

Uji t statistic dengan $\mathrm{T}$ test 12,34 , dengan tingkat signifikan 0,000 , Variabel kualitas produk (X1)

\section{Charts}

memberikan nilai koefisien sebesar 0,859 dengan tingkat signifikansi $0,000 \quad(<0,05)$. Variabel pelayanan (X3) memberikan nilai koefisien sebesar -0,244 dengan tingkat signifikansi $0,000 \quad(<0,05)$ dengan tingkat pelayanan rendah terhadap Loyalitas pelanggan, memberikan nilai koefisien sebesar $-0,400$ dengan tingkat signifikansi sebesar 0,000 $(<0,05)$. Variabel moderat 1 yang merupakan interaksi antara kualitas produk (X1) dan pelayanan (X3) ternyata signifikan, sehingga dapat disimpulkan bahwa variabel kepuasan pelayanan (X3) merupakan variabel moderating.

\subsubsection{Multikolonialitas}

Sesuai denganhasil spss dengan grafik yang menghasilakan tingkat hubungan antara lain:

1. Kualitas produk, kulaitas kerja ,Pelayanan tidakberaturanataubanyakterjadid iluargaristandarisasitingkat Loyalitas pelanggan.

2. Denganmoderasiloyalitasdapatm enghasilkanhubungantingkahubu ngansesuaidengangrafikstandaris asiatautelahmasukdengangarissta ndarisasiketingkatLoyalitas pelanggan 


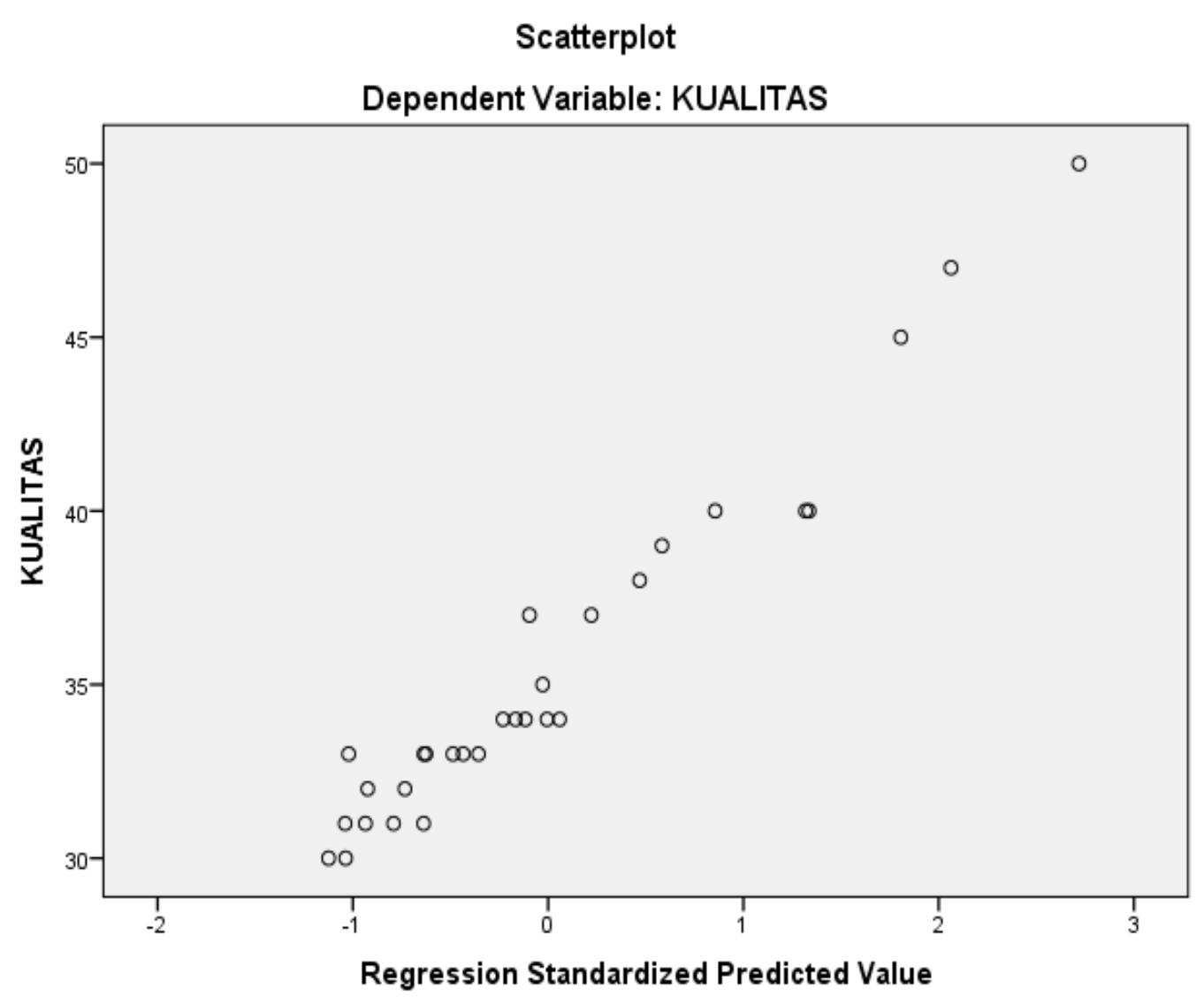




\section{KESIMPULAN :}

1. Berdassarkan pembahasan tersebut diatas dapat dijelaskan bahwa Kualitas Produk .Kualitas Proses ,Kualitas pelayanan berpengaruh signifikan terhadap Kepuasan Pelanggan . Kualitas Produk dim0derasi Kepuasan pelanngan memiliki pengaruh signifikan terhdapa loyalitas pelanggan.Kualitas Proses dimediasi Kepuasan pelanngan berpengaruh signifikan terhadap loyalitas pelanggan Kualilitas pelayanan dimediasi kepuasan pelanggan berpengaruh signifikan terhadap loyalitas pelanggan

2. Secara kuantitatif dapat disimpulkan sebagai berikut .Hubungan Kualitas Produk (X1) dengan Kualitas Proses (X2) kualitas kerja 0,971, Kua pelayanan(X3 ) 0,795sehingga hubungan rata-ratanya 0,883 , dengan di mediasi 0,816 sehingga menghasilakan tingkat kepuasan pelanggan sebesar 0,818 artinya dengan tingkat kepuasan pelanggan 0,818 serta dimediasi sebesar 0,816 menghasilkan tingkat Loyalitas pelanggan sebesar 0,832 mengalani peningkatan tinggkat Loyalitas pelanggan sebesar 0,67 terhadap kualitas produk, kualitas proses serta kualitas pelayanan. Hubungan kualitas proses (X2) dengan kualitas produk (X1) 0,971, Tingkat Pelayanan(X3) 0,846, rata-rata hubungan 0,908 dimediasi sebesar 0,850 menghasilkan tingkat Loyalitas pelanggan 0,842, dengan mediasi sebesar 0,850 menghasilkan tingkat Loyalitas pelanggan rata-rata 0,58 terhadap kualitas kerja, kualitas produk dan tingkat pelayanan. Hubungan Tingkat pelayanan (X3) dengan kualitas produk (X1) 0,795, kualitaskerja (X2) 0,846 dengan rata-rata 0,820 dengan mediasi 0,971 mengahsilkan tinggkat kepuasan pelanggan 0,826. Jadi dengan mediasi 0,971mengahasilakan tinggkat mediasi sebesar 0,771. Yang mana rata-rata hubungan sebesar 0,820 dengan mediasi 0,971 menghasilakan tingkat ke Loyalitas pelanggan rata-rata sebesar 0,151.artinya hubungan yang telah terjalin baik tidak memerlukan tingkat mediasi.

3. KoefisienDeterminasi Nilai Adjusted $R$ Square (R2) sebesar 0,942, artinya 94\% variasi $\mathrm{Y}$ dapat dijelaskan oleh variabelindependen kualitas produk ( X1) 0,859, kualitas kerja ( X2) 0,244danpelayanan X3 -0,058, yang manating katkualitas kerja dan pelayanan sangat rendah terhadap Loyalitas pelanggan. Sisanya $(100 \%-94,0 \%=$ $06,0 \%$ ) dijelaskan olehs ebab-sebab lain di luar model.

4. Uji Signifikansi Simultan (UjiStatistik F) Uji Anova atau $F$ test menghasilkan nilai $\mathrm{F}$ hitung sebesar 95,87dengan tingkat signifikansi 0,000 . Karena probabilitas signifikansi jauh lebih kecildari 0,05, maka model regresi dapat digunakan untuk memprediksi Loyalitas Pelanggan (Y) atau dapat dikatakan bahwa kualitas Produk (X1) , Pelayanan (X3), dan secara bersama-samaberpengaruh terhadap Loyalitas Pelanggan(Y)

\section{Daftar Pustaka}

Boyd, Harper W; Orville C Walker; dan Jean-Claude Larreche. 2000. Manajemen Pemasaran Suatu Pendekatan Strategis dengan 
Orientasi Global. Alih bahasa: Imam Nurmawan. Jakarta: Erlangga.

Prita Saraswati,Srikandi Kumadji ,Yusri Abdillah, urnal Administrasi Bisnis (JAB)|Vol. 14 No. 1 September 2014| administrasibisnis.studentjournal.ub. ac.id

Chandra, Gregorius; Fandy Tjiptono; dan Yanto Chandra. 2004. Pemasaran Global: Internasionalisasi dan Internetisasi. Yogyakarta: ANDI.

Churchill, Gilbert A. 2005. Basic Marketing Research Jilid 2.Alih bahasa E. Koswara, Dira Salam, dan Alvin Ruzhendi. Jakarta: Erlangga.

Griffin, Jill. 2003. Costumer Loyalty: How to Earn It, How to Keep It. Alih bahasa: Benyamin Molan. Jakarta: Erlangga.

Hurriyati, Ratih. 2008. Bauran Pemasaran dan Loyalitas Konsumen: Fokus pada Konsumen Kartu Kredit Perbankan. Bandung: Alfabeta.

Keegan, Warren. J. 2003. Manajemen Pemasaran Global. Alih bahasa: Aris Ananda. Jakarta: Indeks Kelompok Gramedia.

Kotler, Philip dan Gary Armstrong. 2003. Dasar-dasar Pemasaran Jilid 1. Alih bahasa: Alexander Sindoro. Jakarta: Indeks Kelompok Gramedia.

Kristanto, Jajat. 2011. Manajemen Pemasaran Internasional, Sebuah Pendekatan Strategi. Jakarta: Erlangga.
Lury, Cellia. 1998. Budaya Konsumen. Alih bahasa: Hasti Champion. Jakarta: Yayasan Obor Indonesia.

Machin, David dan Michael J. Campbell. 1987. Statistical Table for the Design of Clinical Trial. London: Blackwell Scientific Publication.

Moon, Youngmen and John Quelch. 2004. Starbucks: Delivering Costumer Service. Cambridge: Harvard Business School.

Mowen, John. C dan Michael Minor. 2001. Perilaku Konsumen. Alih bahasa: Dwi Kartini Yahya. Jakarta: Erlangga. 